\title{
Quantification of the neurons of myenteric plexus of the bat molossus rufus ${ }^{1}$
}

\author{
Grazielli F. Serenini² ${ }^{\mathbb{D}}$, José Matheus Beltrami ${ }^{2}$, Edson Gerônimo², \\ Paula M. Favetta ${ }^{2}$, Nathalia G.E. Legnani ${ }^{4}$, Luciana K. Otutumi ${ }^{2}$, \\ Lisiane A. Martins ${ }^{3}$ (D) and Ricardo M. Germano ${ }^{2 *}$ (D)
}

\begin{abstract}
Serenini G.F., Beltrami J.M., Gerônimo E., Favetta P.M., Legnani N.G.E., Otutumi L.K., Martins L.A. \& Germano R.M. 2020. Quantification of the neurons of myenteric plexus of the bat Molossus rufus. Pesquisa Veterinária Brasileira 40(6):493-500. Graduate Program in Animal Science with emphasis in Bioactive Products, Universidade Paranaense, Praça Mascarenhas de Moraes 4282, Zona III, Umuarama, PR 87502-210, Brazil. E-mail: prof.ricardogermano@gmail.com

There are no studies that characterize the enteric nervous system (ENS) bats. The organization and density of myenteric neurons may vary according to the animal species, as well as the segment of the digestive tube considered. The nitric oxide is one of the key neurotransmitters present in the myenteric neurons, acting as a mediator in the smooth muscle relaxation. These neurons are evidenced by immunohistochemistry of nitric oxide synthase (NOS) or by NADPH-diaphorase histochemistry. In this sense, this study aimed to characterize the total neuronal population and subpopulation NADPH- $\mathrm{d}^{+}$of the myenteric plexus present in the jejunum of the insectivore species Molossus rufus quantitatively. Five specimens were collected of M. rufus in a buffer area of the "Reserva Biológica das Perobas" in the microregion of Cianorte/PR. After the euthanasia, in a chamber saturated with isoflurane, segments were collected from the small intestine corresponding to the jejunum intended for two techniques for neuronal marking, Giemsa and NADPH-diaphorase, and a fragment to the histological technique of hematoxylin-eosin and Masson's trichrome. All the procedures were approved by the "Comitê de Ética no Uso de Animais Unipar" (CEUA - protocol No. 34347/2017) and the "Instituto Chico Mendes de Conservação da Biodiversidade" (ICMBio - protocol No. 60061-1) The histological sections allowed to highlight the location of the myenteric plexus between the longitudinal and circular layers of the muscular tunic. The myenteric plexus had an average of total neuronal population (neurons Giemsa+) of 279.23 neurons $/ \mathrm{mm}^{2}$, being the nitrergic neurons (neurons NADPH- $\mathrm{d}^{+}$) represented $20.4 \%$ of this total population, with an average of 58.14 neuron $/ \mathrm{mm}^{2}$. Therefore, the collected data are consistent with previous studies in other mammalian species concerning the location of the myenteric plexus, as well as the neural myenteric proportion NADPH- $\mathrm{d}^{+}$compared with the population of neurons Giemsa+ ${ }^{+}$The gaps in the knowledge of ENS of bats limits comparative intraspecific and interspecific studies.
\end{abstract}

INDEX TERMS: Neurons, myenteric plexus, bats, Molossus rufus, Molossidae, digestive tube, enteric nervous system, NADPH-diaphorase, morphology.

${ }^{1}$ Received on October 17, 2019.

Accepted for publication on November 22, 2019.

${ }^{2}$ Graduate Program in Animal Science with emphasis in Bioactive Products, Universidade Paranaense (Unipar), Praça Mascarenhas de Moraes 4282, Zona III, Umuarama, PR 87502-210, Brazil. *Corresponding author: grazielli.serenini@gmail.com, prof.ricardogermano@gmail.com

${ }^{3}$ Veterinary practitioner, Rua da Amizade 488, Recanto Azul, Botucatu, SP 18603-030, Brazil.

${ }^{4}$ Graduate Program in Nutrition, Universidade Paranaense (Unipar), Praça Mascarenhas de Moraes 4282, Zona III, Umuarama, PR 87502-210, Brazil.
RESUMO.- [Quantificação dos neurônios do plexo mientérico de morcegos da espécie Molossus rufus.] Não há estudos que caracterizem o sistema nervoso entérico (SNE) destes animais, configurando uma lacuna no conhecimento quanto à biologia destes indivíduos. A organização e densidade dos neurônios mientéricos podem variar de acordo com a espécie animal bem como o segmento do tubo digestório considerado. O óxido nítrico é um dos principais neurotransmissores 
presentes nos neurônios mientéricos, atuando como mediador no relaxamento do músculo liso gastrointestinal, de modo que estes neurônios são evidenciados igualmente pela imunohistoquímica da óxido nítrico-sintase (NOS) ou pela histoquímica da NADPH-diaforase. Neste sentido, objetivouse caracterizar quantitativamente a população neuronal total e subpopulação NADPH-d ${ }^{+}$do plexo mientérico presente no jejuno da espécie Molossus rufus de hábito alimentar insetívoro. Foram coletados cinco espécimes de M. rufus em área de amortecimento da Reserva Biológica das Perobas na microrregião de Cianorte/PR. Após a eutanásia, em câmara saturada com isoflurano, foram coletados segmentos do intestino delgado correspondentes ao jejuno destinados a duas técnicas para marcação neuronal, Giemsa e NADPH-diaforase e, um fragmento para a técnica histológica de hematoxilina-eosina e tricômio de Masson. Todos os procedimentos realizados foram aprovados pelo Comitê de Ética no Uso de Animais da Unipar (CEUA - protocolo nํㅜ 34347/2017) e pelo Instituto Chico Mendes de Conservação da Biodiversidade (ICMBio protocolo no 60061-1) Os cortes histológicos possibilitaram evidenciar a localização do plexo mientérico entre os estratos longitudinal e circular da túnica muscular. Neurônios Giemsa+ apresentaram uma média de 279,23 neurônios $/ \mathrm{mm}^{2}$, já os neurônios nitrérgicos apresentaram em média 20,4\% da população neuronal mientérica total, sendo evidenciados 58,14 neurônios NADPH- $\mathrm{d}^{+} / \mathrm{mm}^{2}$. Portanto, os dados coletados mostram-se condizentes com estudos anteriores em outras espécies de mamíferos quanto à localização do plexo mientérico, bem como, a proporção neuronal mientérica NADPH- ${ }^{+}$ comparada com a população de neurônios Giemsa ${ }^{+}$. As lacunas existentes quanto ao conhecimento do SNE de morcegos limita possíveis inferências em comparativo intraespecífico e interespecífico.

TERMOS DE INDEXAÇÃO: Neurônios, plexo mientérico, morcegos, Molossus rufus, molossídeos, tubo digestório, sistema nervoso entérico, NADPH-diaforase, morfologia.

\section{INTRODUCTION}

The bats are animals with acknowledged importance in the dynamics of ecosystems, given the fact that the wide variety of food habits (Sazima etal. 1982, Bianconi et al. 2004). Insectivores, for example, serve as controllers of insect populations (Sipinski \& Reis 1995). Medellín et al. (2000) emphasize that the bats can help as parameters for the identification of biological processes in terms of habitats, being the presence or not of the bats, an indicator of disturbed areas.

In Brazil, it is reported the occurrence of nine families, 68 genera and 178 species, of these, eight genera and 29 species are representatives of the Molossidae family, and among the different species of subfamily Molossinae, there is the Molosus rufus (Nogueira et al. 2014).

Molossus rufus (E. Geoffroy, 1805), insectivore, being restricted to flying insects (Wilson 1973), has as characteristic a tail beyond the interfemoral membrane, having a significant number of individuals inhabiting mainly residential buildings (Peracchi et al. 2011).

The food habits can elucidate, in addition to the characteristics already known, anatomorphological differences, and it can configure distinctions in the Enteric Nervous System (ENS).
ENS is present along the digestive tube since the esophagus to the anus (Gabella 1990, Furness 2006).

Composed of small sets of nerve cells, enteric ganglia, as well as neural connections among them, the nerve fibers (Furness 2012), the submucous and myenteric plexus stand out, which act in the control of the motility, secretions and blood flow of the digestive tube, exerting influence on the absorption of nutrients (Costa et al. 2000, Schemann \& Neunlist 2004, Phillips \& Powley 2007), consisting of motor neurons, interneurons and sensory neurons (Furness \& Costa 1980).

The myenteric plexus is located between the longitudinal and circular layers of the muscular tunic (Furness 2006), being that the organization and density of neurons may vary according to the animal species as well as the segment of the studied digestive tube (Irwin 1931).

Regarding the neurotransmitters expressed in neurons of the myenteric plexus, many have already been identified, among them the nitric oxide (NO), produced and released only when the enzyme nitric oxide synthase (NOS) becomes active (Furness 2006). It is possible to can sort the neurons of the myenteric plexus according to the neurotransmitter associated to it: catecholaminergic or adrenergic, cholinergic and non-adrenergic-non-cholinergic (NANC) (Paran et al. 2009).

NO is a neurotransmitter that acts as NANC mediator in the relaxation of the gastrointestinal smooth muscle (Brookes 1993), being reported as one of the most important inhibitory neurotransmitters of the intestine (Ekblad et al. 1994, Stebbing 1998, Chen et al. 2002) due to its presence in different biological reactions (Knowles \& Moncada 1994, Rosselli et al. 1998), as participation in intestinal homeostasis and elimination of parasites (Halliez \& Buret 2015), an association of inflammatory responses caused by parasites and apoptotic induction (Arantes et al. 2004, Nishikawa et al. 2007) and as a co-factor in diabetic neuropathy (Stevens et al. 1995).

Histochemical and immunohistochemical methods have already proved to be equivalent efficacy in evidencing nitregic neurons (Belai et al. 1992, Santer 1994, Saffrey 2004); those who express NOS, in a way that the NADPHdiaphorase histochemistry (Scherer-Singler et al. 1983) and the immunohistochemistry of NOS (Fabricius et al. 1996) show the same distribution of this subpopulation of neurons.

Phillips et al. (2003) highlight that $98 \%$ of the total myenteric population corresponds to the sum of the cholinergic and nitrergic population. Based on this premise and in the absence of descriptive studies regarding the ENS of bats, the objective of this study was to quantify the total population of neurons of the jejunum of myenteric bats of the species $M$. rufus as well as the subpopulation of the neurons NADPH-diaphorase ${ }^{+}$.

\section{MATERIALS AND METHODS}

The collection of the specimens of Molossus rufus was authorized by "Instituto Chico Mendes de Conservação da Biodiversidade" (ICMBio - Protocol No. 60061-1) and the procedures were approved by the "Comitê de Ética no Uso de Animais Unipar" (CEUA - protocol number 34347/2017).

Collection of specimens. Five specimens of bats Molossus rufus were collected, in residence of the rural area located in the municipality of São Tomé, in the micro region of Cianorte, Paraná State, Brazil. The residence in question housed a large colony of molossidae, in view of the proximity with the urban area and riparian forest. 
The selected microregion is configured as an area of buffer of the Biological Reservation of Perobas (Brasil 2012) (Fig.1), characterizing an ecological corridor for different species. The exact location of the collection area was designated via GPS (Global Positioning System), being $23^{\circ} 51^{\prime} 38.99^{\prime \prime} \mathrm{S}$ and $52^{\circ} 60^{\prime} 91.70^{\prime \prime} \mathrm{W}$.

Two mist nets positioned in places of the animals' leaving, before sunset were used. The bats started their leaving around 06:00 p.m., so that the number of required specimens were obtained along a time of collection, after this period, the nets were withdrawn.

The animals were collected randomly, regardless of sex, being kept only the adult individuals. The identification of the animals captured was performed according to Vizzoto \& Taddei (1973), Gregorin \& Taddei (2002) and Ramos et al. (2013).

In order to minimize possible causative factors of stress, the animals were housed in cotton individual bags so that they could be sent to the Laboratory for Experimental Morphology of the Graduate Program in Animal Science with emphasis in Bioactive Products of "Universidade Paranaense", Umuarama, Paraná.

The euthanasia of each animal was carried out in camera saturated with isoflurane (1 to 3\%). After confirmation of death, laparotomy was performed by the middle line of the anal region until the sternum. The collection of small intestines, corresponding to the jejunal segment was divided into two fragments of equal size, so that each one was subjected to two techniques for marking of neurons. A third fragment of jejunum, half a centimeter, was intended to routine histological processing, stained by hematoxylin-eosin (HE) and masson's trichrome (MT) in order to find the myenteric plexus.

Detection of myenteric neurons Giemsa ${ }^{+}$: disclosure of total neuronal population (Barbosa 1978). Fragments of the jejunum of each animal were intended to evidence the total population of myenteric neurons Giemsa ${ }^{+}$. The segments were washed with saline solution at $0.9 \%$, filled and immersed in a fixing solution of Giemsa, respecting the minimum time for total fixation, 48 hours, remaining

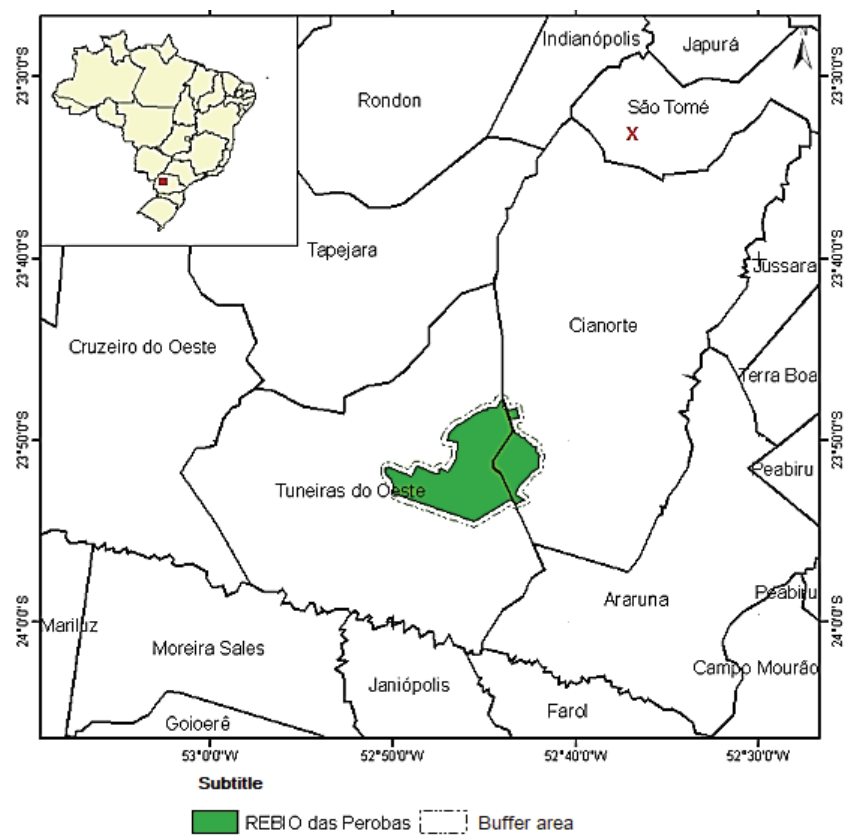

Fig.1 Location of the Biological Reservation of Petrobras, coverage area and buffer zone. The municipality of São Tomé (X), in the micro region of Cianorte, represents the site of the collection area. Adapted from: Brasil 2012. in this solution until obtaining the membrane formulations. To keep the filling, the ends of the jejunum were tied with suture.

After the period of fixation, the straps of the jejunum were removed, and this was sectioned along the longitudinal axis at the level of the insertion of the mesentery. Next, each fragment was micro dissected to the stereomicroscope with transillumination, removing the mucosal tunic as well as the submucous mesh. The muscle and serous tunics were preserved, which constituted the membrane formulations.

Each membrane was immersed in a solution containing Giemsa dye methylene blue in phosphate buffer of Sorense ( $\mathrm{pH} \mathrm{6.9)} \mathrm{for}$ 18 hours at ambient temperature. Then, they were dehydrated in sequence of alcohols (95\% and Absolute I for one minute each, Absolute II for five minute) and then diaphanized in xylol (Xylol I and II for five minutes each). At the end, each membrane was placed between slide and glass plate with synthetic resin.

Detection of myenteric neurons NADPH-d ${ }^{+}$: disclosure of neuronal nitrergic subpopulation (Scherer-Singler et al. 1983). Fragments of the jejunum collected were subjected to histochemical technique of Nicotinamide Adenine Dinucleotide Phosphate-Diaphorase (NADPH-d). For this, the segments of jejunum were washed with phosphate buffer solution (PBS) (pH 7.4). After that, the edges were tied with suture wires so that the interior stayed filled with PBS. In the sequence, the fragments were immersed in paraformaldehyde $4 \%$ for 30 minutes and then washed in PBS containing Triton X-100 $0.3 \%$ for 10 minutes.

After that, the fragments of the jejunum were again washed, for three more times (10 minutes each), in PBS and incubated for 90 minutes in the reaction medium containing $50 \mathrm{mg}$ of Nitro Blue Tetrazolium (NBT), $100 \mathrm{mg}$ of $\beta$-NADPH and $0.3 \%$ of Triton X-100 in Tris-HCl buffer (0.1M, pH 7.6). After the permeabilization, segments of jejunum were again washed in PBS, three times (five minutes each), and at the end of this period, the suture wires were removed on one end and the fragments were immersed in a solution of $4 \%$ paraformaldehyde for the interruption of the reaction, fixation and storage.

Later, the fragments of the jejunum were sectioned along the longitudinal axis at the level of the insertion of the mesentery and from these, membrane formulations were obtained, following the same procedures already described for the microdissection technique of Giemsa staining.

The obtained membrane preparations followed for dehydration in ascending sequence of alcohols (80\%, 90\%, Absolute I and Absolute II) followed of diaphanization in xylol (I and II). After concluding such procedures, the membrane formulations were placed between slide and glass plate with synthetic resin.

Quantification of neurons evidenced by Giemsa technique and histochemistry of NADPH-D. The delimitation of the mesenteric, intermediate and anti-mesenteric areas of the jejunum was done in accordance with Sant'Ana et al. (1997), as a way of guidance for the capture of images, in order to sample the three areas equally. The obtained material was visualized under light microscope (Nikon Eclipse E200), with a 40x objective lens, and a system of image analysis coupled to high resolution camera (Moticam 5.0 megapixels), being transferred to the computer.

Images were captured in 60 random microscopic fields per membrane being contemplated the mesenteric, intermediate and anti-mesenteric areas of the jejunum, intended for the quantitative analysis of the myenteric neurons stained by Giemsa technique and by histochemistry NADPH- $\mathrm{d}^{+}$. Halves neurons were considered in alternate fields. 
Statistical analysis. The obtained data were subjected to descriptive analysis, using the program BioEstat 5.0 (Ayres et al. 2007). The number of total myenteric neurons (Giemsa+) and the number of nitrergic myenteric ones (NADPH- $\mathrm{d}^{+}$), per $\mathrm{mm}^{2}$, were obtained for each animal, and the mean, standard deviation and coefficient of variation were obtained for both.

\section{RESULTS}

The analysis of the histological sections revealed the location of the myenteric plexus for Molossus rufus between the longitudinal and circular layers of muscular tunic and the presence of collagen fibers involving the myenteric ganglion.

Observed to the light microscope, neurons of the myenteric plexus of M. rufus were organized into ganglia mostly composed of several cell bodies, but isolated neurons were also found among the nerve fibers that interconnect the ganglia. The area sampled for each fragment of jejunum was $3.66 \mathrm{~mm}^{2}$ corresponding to 60 microscopic fields. Figure 2 presents the neuronal density per $\mathrm{mm}^{2}$ specimen studied.

In Table 1 the following are expressed: the means \pm standard deviation and the coefficient of variation of populations of total myenteric neurons (Giemsa ${ }^{+}$) and subpopulation NADPH- $\mathrm{d}^{+}$of the jejunum of $M$. rufus estimated per $\mathrm{mm}^{2}$ of each specimen studied.

For the membrane formulations stained by Giemsa technique an average was evidenced of $279.23 \pm 32.42$ neurons $/ \mathrm{mm}^{2}$ and, for the histochemistry NADPH-diaphorase, average of $58.14 \pm 17.48$ neurons $/ \mathrm{mm}^{2}$ (Table 1 ).

Table 1. Mean of total populations of myenteric neurons (Giemsa+) and subpopulation of NADPH-d + neurons of the jejunum of bat insectivore Molossus rufus evidenced by $\mathbf{~ m m}^{2}$.

\begin{tabular}{cccc}
\hline Technique & Mean & S.D. & C.V.\% \\
\hline Giemsa & 279.23 & \pm 32.42 & 11.61 \\
NADPH-d & 58.14 & \pm 17.48 & 30.08
\end{tabular}

S.D. = Standard deviation, C.V. = coefficient of variation.

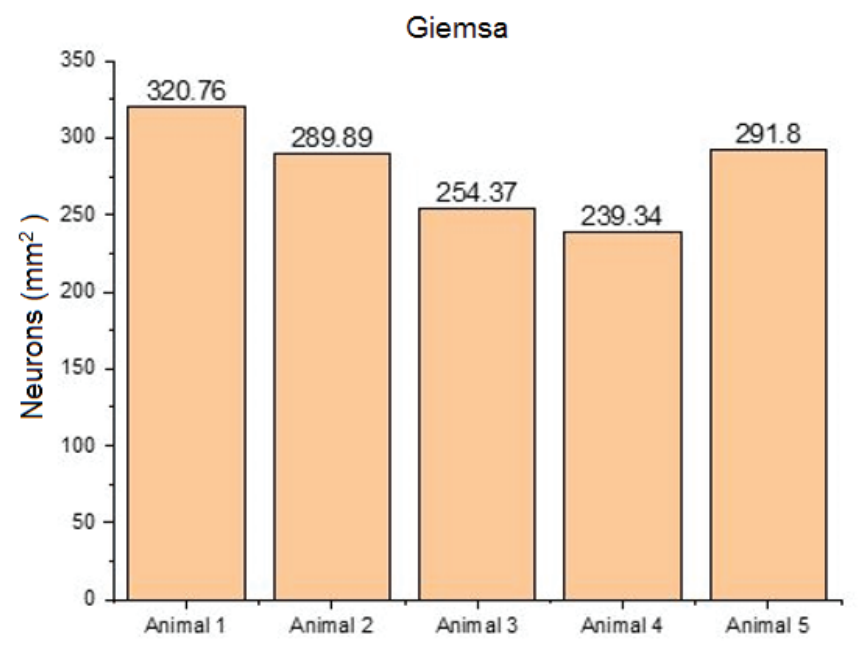

\section{DISCUSSION}

Having this study discussed the quantification of myenteric neurons of the jejunum of a species of insectivore bat, and there not being data in the literature regarding the characteristics of Enteric Nervous System (ENS) for bats in general, different studies with animal models were used, not only mammals, presuming the phylogeny occupied by different groups.

The location of the myenteric plexus of Molossus rufus is consistent with the described by Furness (2006), which highlights the importance of preserving the muscular tunic in the process of obtaining the membrane formulations, once that the myenteric plexus is located between the longitudinal and circular layers of muscular tunic.

Characteristics of the ganglionic arrangement of myenteric plexus are described in several studies (Sant'Ana et al. 1997, Germano et al. 2000, Stabille et al. 2000, Yang et al. 2013) that mention differences in this arrangement depending on the intestinal segment and the species studied (Irwin 1931, Furness \& Costa 1980, Gabella 1990, Furness 2006) as well as in different food habits (Stabille et al. 2002, Münnich et al. 2008, Previato do Amaral et al. 2017).

Bundles of collagen fibers involved the myenteric ganglia in M. rufus, data also found in fish, described by Germano et al. (2000).

The specimens collected in spite of presenting different genders, four males and one female, it has been observed that for $M$. rufus the ganglionic organization of myenteric neurons does not differ among the individuals, the neurons were grouped into ganglia, having the same irregular formats and sparse distribution of isolated neurons among the fibers that interconnect the ganglia.

Assuming the phylogenetic evolution of the ENS, consider the interspecific differences such as feeding habits, region of collection of the studied intestinal fragments and body mass, as well as the intraspecific ones, which consider the morphofunctional and quantitative alterations of the myenteric plexus in animals with different ages, between the different intestinal regions, as well as the organ region sampled, are

Fig.2 Population of total myenteric neurons (Giemsa+) and subpopulation of myenteric nitrergic neurons (NADPH-d+) evidenced by mm² per animal. 
essential to the understanding of the above considerations. It is therefore conjectured that increased or decreased expression of NADPH- $\mathrm{d}^{+}$neurons correlates not only with metabolic status, but also with age, compensation for neuronal loss, and region of intestinal specimen collection.

Furlan et al. (2002) in morphoquantitative study with Wistar rats, report that the majority of myenteric neurons were found grouped in ganglia, being rare, isolated neurons. Germano et al. (2000) observed ganglia of sparse distribution, containing two or more neurons, and also isolated neurons in Cyprinus carpio, highlighting the location of the myenteric plexus between the longitudinal and circular layers of muscular tunic.

Previato do Amaral et al. (2017) in exploratory and descriptive study of the myenteric plexus of broilers (Gallus gallus domesticus) for NADPH- $\mathrm{d}^{+}$neurons in the duodenum, evidenced nitrergic neurons in both, ganglion arrangements and arranged in isolation among the fibers that interconnect the ganglia.

The data found for M. rufus bats in this study are similar to those described by the authors for the respective species studied, Rattus norvegicus, C. carpio and G. gallus domesticus (rat, fish and broiler). The data sampled by the different authors, as well as those from this study, converge to aspects of the phylogenetic evolution already described for the enteric nervous system (Furlan, 2000). Different studies reinforce this phylogeny, in fish neurons are predominantly isolated (Germano et al. 2000) and from chickens this conformation is inverted, with myenteric neurons predominantly organized in ganglia (Gabella \& Halasy 1987).

Regarding the neuronal disclosure of proximal colon of adult rats, Furlan et al. (2002) showed an average of 5122 neurons Giemsa ${ }^{+}$in $17.68 \mathrm{~mm}^{2}$, these being corresponding to an average of 289.70 neurons $/ \mathrm{mm}^{2}$. Germano et al. (2000), in the intestinal bulb of carps, quantified an average of 2040 neurons Giemsa+ in $6.92 \mathrm{~mm}^{2}$, equivalent to 294.79 myenteric neurons Giemsa ${ }^{+} / \mathrm{mm}^{2}$. Compared to the results of this study, the neuronal population Giemsa ${ }^{+}$among the different species are similar (Table 1 ).

Ferezin et al. (2017) reported the count of approximately 45 neurons Giemsa+ in $0.249 \mathrm{~mm}^{2}$, corresponding to 180.72 neurons $/ \mathrm{mm}^{2}$ and 12 neurons NADPH- $\mathrm{d}^{+}$in $0.249 \mathrm{~mm}^{2}$, equivalent to 48.19 neurons $/ \mathrm{mm}^{2}$ for the colon of rats.

Previato do Amaral et al. (2017) found a mean \pm standard deviation of $24.38 \pm 4.97$ neurons NADPH- $\mathrm{d}^{+} / \mathrm{mm}^{2}$ in the duodenum of broilers, values which were lower than the values found in the present study, 58.14 \pm 17.48 neurons NADPH- $\mathrm{d}^{+} / \mathrm{mm}^{2}$.

Yang et al. (2013) found 58.88 \pm 3.16 neurons NADPH- $\mathrm{d}^{+} /$ $\mathrm{mm}^{2}$ in the jejunum of broilers aged 15 days, and $45.92 \pm 17.51$ neurons NADPH- $\mathrm{d}^{+} / \mathrm{mm}^{2}$ for broilers aged 40 days. Compared to the values of nitrergic neurons found in M. rufus, the results were similar although differences are expected among the species.

The mean of inhibitory neurons, as evidenced in this study, corresponds to $20.4 \%$ of the population of myenteric neurons evidenced by Giemsa technique, it is highlighted that the results fall within the expected parameters, once that they resemble those of Ekblad et al. (1994), who found $21 \%$ of neurons containing NOS in the small intestine of rats. Other studies have found a percentage next to those, $23 \%$ for guinea-pigs (Furness 2006), 29\% in rats (Qu et al. 2008) and $34 \%$ in humans (Wester et al. 1999).

A smaller number of marked inhibitory neurons (nitrergic) does not necessarily indicate a lower number of nitrergic neurons, because the enzyme present in the reaction of the neuronal nitrergic marking in the NADPH-d technique, shows only those neurons with NOS activity at the time of the reaction (Scherer-Singler et al. 1983).

Considering that for the total neuronal myenteric population, the coefficient of variation presented is not expressive, $11.61 \%$ (Table 1), confirming a similarity between the samples and the studied individuals, differing only concerning the number of nitrergic neurons in activity at the time of collection.

Regarding the studies on the bats' digestive tube, they stand out for their histology (Makanya et al. 2001, Gadelha-Alves et al. 2008, Strobel et al. 2015, Zhang et al 2015) and microbiology (Ingala et al. 2018, Sens Junior et al. 2018). However, BarryJr (1976) already emphasized the little research about the different segments of this system, including the intestine to wild mammals, a real fact still today, once that the studies on ENS are widely disseminated to rodents (Karaosmanoglu et al. 1996, Tan et al. 2008, Luesma et al. 2013, Grundmann et al. 2015, Kulkarni et al. 2017) and more recently to primates (Noorian et al. 2011), but in terms of other groups of wild mammals, not employed in experimental models, the absence of data is notorious.

Gadelha-Alves et al. (2008), emphasizes the importance of the study of the bats' digestive system, aiming to understand the factors associated with it, such as environmental changes originated from anthropic action in their habitats.

Zhang et al. (2015), upon comparing the surface of the mucosa of the small intestine of Tadarida brasiliensis, also an insectivore bat, and the species Mus musculus discussed the high digestive capacity of bats in association with the higher density of villi and enterocytes, corresponding to a higher paracellular permeability per $\mathrm{cm}^{2}$ in the bats. The authors also emphasize to the digestive capacity and its relation with the flight efficiency of these animals, demonstrating a digestive complex of high capacity, despite their small body mass.

In this sense it is worth mentioning that the myenteric neurons coordinate the intestinal movements, interfering not only in the intestinal transit, but also in the absorption capacity (Costa et al. 2000, Schemann \& Neunlist 2004, Phillips \& Powley 2007).

Considering the time of the capture of animals for this study before the start of the foraging, a lower inhibitory neuronal expression can be considered. Thus, the density of nitrergic inhibitory myenteric neurons is not related only to morphological adaptations and the diet of the animal, but also with its metabolic state at the time of marking those neurons, i.e., whether the neurons that express NOS are active or not (Scherer-Singler et al. 1983).

Gabella (1990) emphasizes that the extension of the intrinsic neuronal population of the intestine reflects the importance of the functions of the same for the survival of the animal especially in nature, in view the high level of adaptability to variation in food contents and feeding time, require a well-developed nervous control.

However, the absence of an effective blood-neuron barrier (Furness 2006) and the high paracellular absorption capacity of the bats (Fasulo et al. 2013) leave these animals very 
susceptible to exposure to toxins present in environments subject to change by human occupation, and by chance, in their food, which could compromise the neuronal population. It is therefore highlighted the importance of this exploratory and quantitative study of myenteric neuronal population of bats, corroborating with a better understanding of these individuals in their entirety.

\section{CONCLUSIONS}

The myenteric plexus in bats of the species Molossus rufus is located between the longitudinal and circular layers of muscular tunic, while neurons organized into ganglia surrounded by collagen fibers, presenting a few isolated neurons among the nerve fibers.

Variations in the total population of myenteric neurons is expected among the different species as well as in different segments of the digestive tube. The mean of the subpopulation of active nitrergic neurons in the studied species is consistent with that described for different species of animals of different classes, assuming a variation from 20 to $35 \%$.

The quantification of the total population of myenteric neurons and the nitrergic subpopulation contributes to know the morphology and function of the enteric nervous system (ENS) in bats, since these are distinguished from other mammals by the ability to true flight, besides helping in understanding the intestinal anatomy peculiar to these individuals, described as proportionately small, however with great digestive capacity.

These results can contribute to future research aimed at a better understanding of these animals in the context of unique health.

Acknowledgments.- The authors are grateful to "Universidade Paranaense" (Unipar) that through "Diretoria Executiva de Gestão da Pesquisa e PósGraduação" (DEGPP) supported the development of this research and to "Coordenação de Aperfeiçoamento de Pessoal de Nível Superior" (CAPES), Brazil, for the grant of scholarship to the first author of the article.

Conflict of interests statement.- The authors declare no conflict of interests.

\section{REFERENCES}

Arantes R.M.E., Marche H.H.F., Bahia M.T., Cunha F.Q., Rossi M.A. \& Silva J.S. 2004. Interferon- $y$-induced nitric oxide causes intrinsic intestinal denervation in Trypanosoma cruzi-infected mice. Am. J. Pathol. 164(4):1361-1368. <http://dx.doi.org/10.1016/s0002-9440(10)63222-1><PMid:15039223>

Ayres M., Ayres Júnior M., Ayres D.L. \& Santos A.S. 2007. BioEstat 5.0: Aplicações Estatísticas nas Áreas das Ciências Biológicas e Médicas. Ilustrado, acompanha CD-ROM. Ministério da Ciência e Tecnologia (MCT), Instituto de Desenvolvimento Sustentável Mamirauá (IDSM), CNPq, Belém. 364p.

Barbosa A.J.A. 1978. Técnica histológica para gânglios nervosos intramurais em preparados espessos. Braz. J. Med. Biol. Res. 11:95-97.

Barry-Jr R.E. 1976. Mucosal surface areas and villous morphology of the small intestine of small mammals: functional interpretations. J. Mammal. 57(2):273-290. <http://dx.doi.org/10.2307/1379688><PMid:778319>

Belai A., Schmidt H.H.H.W., Hoyle C.H.V., Hassall C.J.S., Saffrey M.J., Moss J., Förstmann U., Murad F. \& Burnstock G. 1992. Colocalization of nitric oxide synthase and NADPH-diaforase in the myenteric plexus of the rat gut. Neurosci. Lett. 143(1/2):60-64. <http://dx.doi.org/10.1016/03043940(92)90233-w> <PMid:1279479>

Bianconi G.V., Mikich S. \& Pedro W.A. 2004. Diversidade de morcegos (Mammalia, Chiroptera) em remanescentes florestais do município de Fênix, Noroeste do Paraná, Brasil. Revta Bras. Zool. 21(4):943-954. <http://dx.doi.org/10.1590/S0101-81752004000400032>

Brasil 2012. Plano de Manejo da Reserva Biológica das Perobas. Instituto Chico Mendes de Conservação da Biodiversidade, Ministério do Meio Ambiente, Brasília. 199p.

Brookes S. 1993. Neuronal nitric oxide in the gut. J. Gastroenterol. Hepatol. Res. 8(6):590-603. <http://dx.doi.org/10.1111/j.1440-1746.1993.tb01658.x> <PMid:7506586>

Chen Y., Qian Z., Zhang J., Chang Y. \& Duan X. 2002. Distribution of constitutive nitric oxide synthase in the jejunum of adult rat. World J. Gastroenterol. 8(3):537-539. <http://dx.doi.org/10.3748/wjg.v8.i3.537><PMid:12046087>

Costa M., Brookes S.J.H. \& Hennig G.W. 2000. Anatomy and physiology of the enteric nervous system. Gut 47(Supl.4):15-19. <http://dx.doi.org/10.1136/ gut.47.suppl_4.iv15><PMid:11076898>

Ekblad E., Alm P. \& Sundler F. 1994. Distribution, origin and projections of nitric oxide synthase-containing neurons in gut and pancreas. Neurosciense 63(1):233-248. <http://dx.doi.org/10.1016/0306-4522(94)90019-1> <PMid:7534882>

Fabricius M., Rubin I., Bundgaard M. \& Lauritzen M. 1996. NOS activity in brain and endothelium: relation to hypercapnic rise of cereal blood flow rats. Am. J. Physiol. 271(5 Pt 2):H2035-2044. <http://dx.doi.org/10.1152/ ajpheart.1996.271.5.H2035><PMid:8945923>

Fasulo V., Zhang Z., Chediack J.G., Cid F.D., Karasov W.H. \& CaviedesVidal E. 2013. The capacity for paracellular absorption in the insectivorous bat Tadarida brasiliensis. J. Comp. Physiol. B 183:289-296. <http://dx.doi.org/10.1007/s00360-012-0696-1>

Ferezin R.I., Vicentino-Vieira S.L., Góis M.B., Araújo E.J.A., Melo G.A.N., Garcia J.L. \& Sant'Ana. 2017. Different inoculum loads of Toxoplasma gondii induce reduction of myenteric neurons of the rat colon. Braz. J. Vet. Parasitol. 26(1):47-53. <http://dx.doi.org/10.1590/s1984-29612017003>

Furlan M.M.D.P. 2000. Ontogenia e filogenia do sistema nervoso entérico. Arq. Cien. Saúde Unipar 4(2):149-157. <http://dx.doi.org/10.25110/ arqsaude.v4i2.2000.1020>

Furlan M.M.D.P., Molinari S.L. \& Miranda-Neto M.H. 2002. Morphoquantitative effects of acute diabetes on the myenteric neurons of the proximal colon of adult rats. Arq. Neuropsiquiatr. 60(3-A):576-581. <http://dx.doi. org/10.1590/s0004-282x2002000400012><PMid:12244395>

Furness J.B. \& Costa M. 1980. Types of nerves in the enteric nervous system. Neuroscience 5:1-20. <http://dx.doi.org/10.1016/0306-4522(80)90067-6> <PMid:6154268>

Furness J.B. 2006. The Enteric Nervous System. Blackwell Publishing, Massachusetts. 274p.

Furness J.B. 2012. The enteric nervous system and neurogastroenterology. Nat. Rev. Gastroenterol. Hepatol. 9(5):286-294. <http://dx.doi.org/10.1038/ nrgastro.2012.32>

Gabella G. \& Halasy K. 1987. On the nerve plexus of the chicken gizzard. Anat. Embryol.177(2):97-103.<http://dx.doi.org/10.1007/bf00572533> $<$ PMid:3434849>

Gabella G. 1990. On the plasticity of form and structure of enteric ganglia. J. Auton. Nerv. Syst. 30(Supl.):S59-S66. <http://dx.doi.org/10.1016/01651838(90)90103-p><PMid:2212494>

Gadelha-Alves R., Rozensztranch A.M.S. \& Rocha-Barbosa O. 2008. Comparative intestinal histomorphology of five species of Phyllostomid bats (Phyllostomidae, Microchiroptera): ecomorphological relations with alimentary habits. Int. J. Morphol. 26(3):591-602. <http://dx.doi.org/10.4067/S0717-95022008000300014>

Germano R.M., Stabille S.R., Marega P. \& Molinari S.L. 2000. Morphological and quantitative analysis of myenteric plexus neurons of intestinal bulb of Cyprinus carpio (Linnaeus, 1758) (Osteichthyes, Cyprinidae). Acta Scient. Biol. Sci. 22(2):561-565. 
Gregorin R. \& Taddei V.A. 2002. Chave artificial para a identificação de molossídeos brasileiros (Mammalia, Chiroptera). J. Neotrop. Mammal. 9(1):13-32.

Grundmann D., Klatz M., Rabe H., Glanemann M. \& Schäfer K. 2015. Isolation of high-purity myenteric plexus from adult human and mouse gastrointestinal tract. Sci. Rep. 5:9226. <http://dx.doi.org/10.1038/srep09226>

Halliez M.C.M. \& Buret A.G. 2015. Gastrointestinal parasites and the neural control of gut functions. Front. Cell. Neurosci. 9:452. <http://dx.doi. org/10.3389/fncel.2015.0045><PMid:26635531>

Ingala M., Simmons N.B., Wultsch C., Krampis K., Speer K.A. \& Perkins S.L. 2018. Comparing microbiome sampling methods in a wild mamal: fecal and intestinal samples record different signals of host ecology evolution. Front. Microbiol. 9:803. <http://dx.doi.org/10.3389/fmicb.2018.00803> <PMid:29765359>

Irwin D.A. 1931. The anatomy of Auerbach's plexus. Am. J. Anat. 49(1):141166. <http://dx.doi.org/10.1002/aja.1000490106>

Karaosmanoglu T., Aygun B., Wade P.R. \& Gershon M.D. 1996. Regional differences in the number of neurons in the myenteric plexus of the guinea pig small intestine and colon: an evaluation of markers used to count neurons. Anat. Rec. 244(4):470-480. <http://dx.doi.org/10.1002/ (SICI)1097-0185(199604)244:4<470::AID-AR5>3.0.C0;2-Z><PMid:8694282>

Knowles R.G. \& Moncada S. 1994. Nitric oxide synthases in mammals. Biochem. J. 298(Pt 2):249-258. <http://dx.doi.org/10.1042/bj2980249> $<$ PMid:7510950>

Kulkarni S., Micci M., Leser J., Shin C., Tang S., Fu Y., Liu L., Li Q., Saha M., Li C., Enikolopov G., Becker L., Rakhilin N., Anderson M., Shen X., Dong X., Butte M.J., Song H., Southard-Smith E.M., Kapur R.P., Bogunovic M. \& Pasricha P.J. 2017. Adult enteric nervous system in health is maintained by a dynamic balance between neuronal apoptosis and neurogenesis. Proc. Natl. Acad. Sci. USA 114(18):E3709-3718. <http://dx.doi.org/10.1073/ pnas.1619406114><PMid:28420791>

Luesma M.J., Cantarero I., Castiella T., Soriano M., Garcia-Verdugo J.M. \& Junqueira C. 2013. Enteric neurons show a primary cilium. J. Cell. Mol. Med. 17(1):147-153.<http://dx.doi.org/10.1111/j.1582-4934.2012.01657.x> $<$ PMid:23205631>

Makanya A.N., Self T.J., Warui C.N. \& Mwangi D.K. 2001. Gut morphology and morphometry in the epauletted wahlberg's fruit bat (Epomophorus wahlbergi Sundevall, 1846). Acta. Biol. Hung. 52(1):75-89. <http://dx.doi.org/10.1556/ ABiol.52.2001.1.8><PMid:11396843>

Medellín R.A., Equihua M. \& Amin M.A. 2000. Bat diversity and abundance as indicators of disturbance in Neotropical Rainforests. Conserv. Biol. 14(6):1666-1675. <http://dx.doi.org/10.1111/j.1523-1739.2000.99068.x>

Münnich J., Gäbel G. \& Pfannkuche H. 2008. Intrinsic ruminal innervation in ruminants of different feeding types. J. Anat. 213(4):442-451. <http://dx.doi.org/10.1111/j.1469-7580.2008.00959.x><PMid:18657258>

Nishikawa Y., Kawase O., Vielemeyer O., Suzuki H., Joiner K.A., Xuan X. \& Nagasawa H. 2007. Toxoplasma gondii infection induces apoptosis in noninfected macrophages: role of nitric oxide and other soluble factors. Parasite Immunol. 29(7):375-385.<http://dx.doi.org/10.1111/j.1365-3024.2007.00956.x> $<$ PMid:17576367>

Nogueira M.R., Lima I.P., Moratelli R., Cunha Tavares V., Gregorin R. \& Peracchi A.L. 2014. Checklist of Brazilian bats, with comments on original records. Check List, J. Biodiversity Data 10(4):808-821. <http://dx.doi. org/10.15560/10.4.808>

Noorian A.R., Taylor G.M., Annerino D.M. \& Greene J.G. 2011. Neurochemical phenotypes of myenteric neurons in the rhesus monkey. J. Comp. Neurol. 519(17):3387-3401. <http://dx.doi.org/10.1002/cne.22679> <PMid:21618236>

Paran T.S., Rolle U. \& Puri P. 2009. Age-related changes in the myenteric plexus of the porcine bowel. J. Pediatr. Surg. 44(9):1771-1777. <http://dx.doi.org/10.1016/j.jpedsurg.2008.12.018><PMid:19735824>
Peracchi A.L., Lima I.P., Reis N.R., Nogueira M.R. \& Ortêncio-Filho H. 2011. Ordem Chiroptera, p.155-234. In: Reis N.R., Peracchi A.L., Pedro W.A. \& Lima I.P. (Eds), Mamíferos do Brasil. 2 a ed. Londrina, Universidade Estadual de Londrina, Londrina. 439p.

Phillips R.J. \& Powley T.L. 2007. Innervation of the gastrointestinal tract: patterns of aging. Auton. Neurosci. 136(1/2):1-19. <http://dx.doi. org/10.1016/j.autneu.2007.04.005><PMid:17537681>

Phillips R.J., Kieffer E.J. \& Powley T.L. 2003. Aging of the myenteric plexus: neuronal loss is specific to cholinergic neurons. Auton. Neurosci. 106(2):69-83. <http://dx.doi.org/10.1016/S1566-0702(03)00072-9><PMid:12878075>

Previato do Amaral P.F.G., Santos G.R., Urano T.K., Diniz K.S., Gonçalves T.S.A., Serenini G.F., Otutumi L.K. \& Germano R.M. 2017. Salmonella Heidelberg reduces nitrergic neurons in the myenteric plexus of the duodenum of broilers. Afr. J. Microbiol. Res. 11(33):1315-1320. <http://dx.doi. org/10.5897/AJMR2017.8593>

Qu Z.D., Thacker M., Castelucci P., Bagyanszki M., Epstein M.L. \& Furness J.B. 2008. Immunohistochemical analysis of neuron types in the mouse small intestine. Cell Tissue Res. 334(2):147-161. <http://dx.doi.org/10.1007/ s00441-008-0684-7><PMid:18855018>

Ramos P.H.G., Reis N.R. \& Peracchi A.L. 2013. Família Molossidae, p.175-205. In: Reis N.R., Fregonezi M.N., Peracchi A.L. \& Schibatta O.A. (Eds), Morcegos do Brasil, Guia de Campo. Technical Books, Rio de Janeiro, 252p.

Rosselli M., Keller R. \& Dubey R.K. 1998. Role of nitric oxide in the biology, physiology and pathophysiology of reproduction. Hum. Reprod. Update 4(1):3-24.<http://dx.doi.org/10.1093/humupd/4.1.3><PMid:9622410>

Saffrey M.J. 2004. Ageing of the enteric nervous system. Mech. Ageing Develop. 125(12):899-906. <http://dx.doi.org/10.1016/j.mad.2004.09.003> $<$ PMid:15563936>

Sant'Ana D.M.G., Miranda-Neto M.H., Souza R.R. \& Molinari S.L. 1997. Morphological and quantitative study of the myenteric plexus of the ascending colon of rats subjected to proteic desnutrition. Arq. Neuropsquiatr. 55(4):687-695. <http://dx.doi.org/10.1590/S0004-282X1997000500003>

Santer R.M. 1994. Survival of the population of nadph-diaphorase stained myenteric neurons in the small intestine of aged rats. J. Auton. Nerv. Syst. 49(2):115-121. <http://dx.doi.org/10.1016/0165-1838(94)90131-7> $<$ PMid:7806764>

Sazima M., Fabián M.E. \& Sazima I. 1982. Polinização de Luehea speciosa (Tiliaceae) por Glossophaga soricina (Chiroptera, Phyllostomidae). Revta Bras. Biol. 42(3):505-513.

Schemann M. \& Neunlist M. 2004. The human enteric nervous system. J. Neurogastroenterol. Motil. 16(Supl.1):55-59. <http://dx.doi. org/10.1111/j.1743-3150.2004.00476.x > <PMid:15066006>

Scherer-Singler U., Vincent S.R., Kimura H. \& Mcgeer E.G. 1983. Demonstration of unique population of neurons with NADPH-diaphorase histochemistry. J. Neurosci. Methods 9(3):229-234. <http://dx.doi.org/10.1016/01650270(83)90085-7><PMid:6363828>

Sens Junior H., Trindade W.A., Oliveira A.F., Zaniolo M.M., Serenini G.F., Araújo-Ceranto J.B., Gonçalves D.D. \& Germano R.M. 2018. Bacterial resistance in bats from the Phyllostomidae family and its relationship with unique health. Pesq. Vet. Bras. 38(6):1207-1216. <http://dx.doi.org/10.1590/1678-5150-pvb-5185>

Sipinski E.A.B. \& Reis N.R. 1995. Dados ecológicos dos quirópteros da reserva Volta Velha, Itapoá, Santa Catarina, Brasil. Revta Bras. Zool. 12(3):519-528. <http://dx.doi.org/10.1590/S0101-81751995000300006>

Stabille S.R., Alves G.R., Germano R.M. \& Miranda-Neto M.H. 2002. Características gerais dos neurônios mioentéricos do segmento intestinal médio do pacu Piaractus mesopotamicus (Holmberg, 1887) (Teleostei:Serrasalmidae). Arq. Ciênc. Saúde Unipar 6(1):3-9. <http://dx.doi.org/10.25110/arqsaude. v6i1.2002.1143>

Stabille S.R., Marega P., Ribeiro E.A. \& Germano R.M. 2000. Considerações morfológicas e quantitativas sobre os neuronios do plexo mientérico do 
segmento intestinal médio da carpa Cyprinus carpio (Linnaeus, 1758). Arq. Ciênc. Saúde Unipar 4(3):221-227. <http://dx.doi.org/10.25110/ arqsaude.v4i3.2000.1032>

Stebbing J.F. 1998. Nitric oxide synthase neurones and neuromuscular behaviour of the anorectum. Ann. R. Coll. Surg. Engl. 80(2):137-145. <PMid:9623382>

Stevens M.J., Feldman E.L. \& Greene D.A. 1995. The aetiology of diabetic neuropthy: the combined roles of metabolic and vascular defects. Diabet. Med. 12(7):566-579. <http://dx.doi.org/10.1111/j.1464-5491.1995. tb00544.x > <Mid:7554777>

Strobel S., Encarnação J.A., Becker N.I. \& Trenczek T.E. 2015. Histological and histochemical analysis of the gastrointestinal tract of the common pipistrelle bat (Pipistrellus pipistrellus). Eur. J. Histochem. 59(2):2477. <http://dx.doi.org/10.4081/ejh.2015.2477> <PMid:26150154>

Tan L.L., Bornstein J.C. \& Anderson C.R. 2008. Distinct chemical classes of medium-sized transient receptor potential channel vanilloid 1-immunoreactive dorsal root ganglion neurons innervate the adult mouse jejunum and colon. Neuroscience 156(2):334-343. <http://dx.doi.org/10.1016/j. neuroscience.2008.06.071><PMid:18706490>

Vizzoto L.D. \& Taddei V.A. 1973. Chave para determinação de quirópteros brasileiros. Revta. Fac. Ciênc. Letras, São José do Rio Preto, 1:1-72.

Wester T., O'briain D. \& Puri P. 1999. Notable postnatal alterations in the myenteric plexus of normal human bowel. Gut 44(5):666-674. <http://dx.doi.org/10.1136/gut.44.5.666> <PMid:10205203>

Wilson D.E. 1973. Bat faunas: a trophic comparison. Syst. Zool., Londres, 22(1):14-29. <http://dx.doi.org/10.2307/2412374>

Yang P., Gandahi J.A., Zhang Q., Zhang L., Bian X., Wu L., Liu Y. \& Chen Q. 2013. Quantitative changes of nitrergic neurons during postnatal development of chicken myenteric plexus. J. Zhejiang Univ. Sci. B 14(10)886-895. <http://dx.doi.org/10.1631/jzus.B1300005> <PMid:24101205>

Zhang Z.Q., Brun A., Price E.R., Cruz-Neto A.P., Karasov W.H. \& Caviedes-Vidal E.A. 2015. Comparison of mucosal surface area and villous histology in small intestines of the Brazilian free-tailed bat (Tadarida brasiliensis) and the mouse (Mus musculus). J. Morphol. 276(1):102-108. <http://dx.doi. org/10.1002/jmor.20324> 